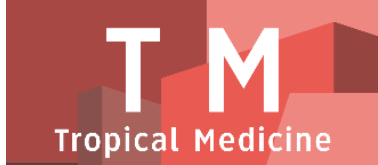

PAPER - OPEN ACCESS

\title{
Aktivitas Sitotoksik Fraksi Alkaloid Kulit Batang dan Buah Attarasa (Litsea cubeba Lour.) terhadap Sel Kanker Payudara T47D
}
Author
: Aminah Dalimunthe
DOI
: 10.32734/tm.v1i3.261
Electronic ISSN
: 2623-0542
Print ISSN
: 2623-0550

Volume 1 Issue 3 - 2018 TALENTA Conference Series: Tropical Medicine (TM)

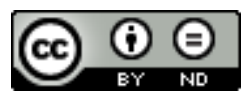

This work is licensed under a Creative Commons Attribution-NoDerivatives 4.0 International License.

Published under licence by TALENTA Publisher, Universitas Sumatera Utara
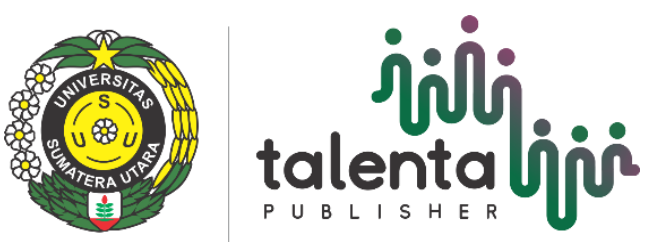


\title{
Aktivitas Sitotoksik Fraksi Alkaloid Kulit Batang dan Buah Attarasa (Litsea cubeba Lour.) terhadap Sel Kanker Payudara T47D
}

\author{
Aminah Dalimunthe ${ }^{a^{*}}$, Poppy Anjelisa Zaitun Hasibuan ${ }^{\mathrm{b}}$, \\ Jansen Silalahi ${ }^{\mathrm{c}}$ Denny Satria ${ }^{\mathrm{d}}$ \\ ${ }^{a b}$ Departemen Farmakologi, Fakultas Farmasi, Universitas Sumatera Utara, Medan 20155 \\ ${ }^{c}$ Departemen Kimia Farmasi, Fakultas Farmasi, Universitas Sumatera Utara, Medan 20155 \\ ${ }^{d}$ Departemen Biologi Farmasi, Fakultas Farmasi, Universitas Sumatera Utara, Medan 20155 \\ aminah@usu.ac.id
}

\begin{abstract}
Abstrak
Kanker payudara adalah salah satu jenis dari kanker yang banyak menyerang wanita selain kanker mulut rahim. Tingginya angka kejadian dan resistensi agen kemoterapi menyebabkan perlu dilakukan pencarian bahan alam dengan aktivitas antikanker. Penggunaan bahan alam diharapkan dapat mengatasi resistensi dan efek samping yang terjadi ketika digunakan kemoterapi konvensional. Tujuan penelitian ini untuk mengetahui aktivitas antikanker fraksi kloroform (alkaloid) kulit batang dan buah attarasa pada sel T47D. Ekstrak etanol diekstraksi dengan cara maserasi dan difraksinasi dengan n-heksana dan kloroform pada pH 3, 7, 9. Pengujian sitotoksik secara in vitro menggunakan metode MTT yang kemudian dianalisis menggunakan SPSS 21. Hasil uji sitotoksik ( $\mathrm{IC}_{50}$ ) yang diperoleh setelah pemberian fraksi alkaloid kulit batang dan buah attarasa $\mathrm{pH} 7$ dan 9 adalah sebesar 46,60 $\pm 0,19 ; 123,01 \pm 14,63$ dan $35,89 \pm 1,04$; dan $98,31 \pm 2,51 \mu \mathrm{g} / \mathrm{mL}$. Fraksi alkaloid kulit batang dan buah attarasa bersifat sitotoksik terhadap sel kanker payudara T47D.
\end{abstract}

Kata kunci: buah, kulit batang, Litsea cubeba Lour., fraksi alkaloid, sel T47D

\begin{abstract}
Breast cancer is one of the cancer which suffered by women after cervical cancer. The high incidence rate and the resistance of chemotherapeutic agents, there is a continuous need to search of natural products with anticancer activity. The use of natural products is expected to resolve resitance and side effect when used conventional chemotheraphy. The aim of our research was to investigate the anticancer activity of chloroform fractions (alkaloid) of attarasa heartwood and fruits towards T47D cells. Ethanol extract were prepared by maceration and continued with liquid-liquid extraction with n-hexane, and chloroform at pH 3, 7, and 9. T47D cells were grown in culture medium RPMI then given by alkaloid fractions. Cytotoxic test in vitro was done by MTT method which is then analyzed using SPSS 21 . The results of this research describe that the cytotoxic results ( IC $\left._{50}\right)$ after treatment with alkaloid fractions at $\mathrm{pH} 7$ and 9 were $46.60 \pm 0.19 ; 123.01 \pm 14.63$ dan $35.89 \pm 1.04 ; 98.31 \pm 2.51 \mu \mathrm{g} / \mathrm{mL}$. Alkaloid fractions of heartwoods and fruits of attarasa have cytotoxic activity towards T47D breast cancer cells
\end{abstract}

Key words: fruits, heartwood, Litsea cubeba Lour., alkaloid fractions, T47D cell line. 


\section{Pendahuluan}

Kanker dikategorikan sebagai suatu penyakit yang kompleks. Kanker menyumbang angka kematian kedua di dunia dan diperkirakan \pm 8 juta orang meninggal akibat penyakit ini [1]. Kanker masih menjadi masalah kesehatan di dunia. Selain angka kejadian dan angka kematian yang tinggi, kanker juga menim bulkan masalah ekonomi. American Cancer Society memperkirakan bahwa sekitar 1.529 .560 penderita baru dan 569.490 jumlah kematian yang terjadi akibat kanker yang terjadi pada tahun 2010 [2]. Jumlah penderita baru tersebut meningkat jika dibandingkan dengan jumlah penderita baru pada tahun 2009 yaitu 50.210. Jumlah biaya yang hilang akibat kematian oleh kanker yaitu sebesar 115,8 milyar dolar Amerika Serikat pada tahun 2000 dan akan mencapai 147,8 milyar pada tahun 2020 [3].

Attarasa (Litsea cubeba Lour.) merupakan tumbuhan dari keluarga Lauraceae yang kaya akan senyawa minyak atsiri. Secara tradisional, minyak atsiri dari attarasa digunakan untuk antidepresan, antiinflamasi, antioksidan, pestisida, antimikroba, antikanker dan neuro farmakologi [4]. Ekstrak metanol buah attarasa memiliki aktivitas terhadap sel HeLa yang menyebabkan apoptosis dengan cara mengaktivasi kaspase 3/7 [5]. Ekstrak etilasetat kulit batang attarasa memiliki aktivitas antioksidan dan memiliki kandungan fenol dan flavonoid total yang tinggi [6]. Tumbuhan dari marga Litsea kaya akan senyawa alkaloid golongan isokuinolin dan lebih dari 40 senyawa alkaloid isokuinolin telah diisolasi dan memiliki aktivitas antibakteri terhadap Staphylococcus aureus [7]. Alkaloid isokuinolin merupakan senyawa alkaloid yang memiliki aktivitas dalam penghambatan kanker melalui jalur P13K/Akt dan mTOR. Selain itu memiliki pengaruh terhadap asam amino dan beberapa protein termasuk telomerase, DNA topoisimerase I, p53, NF-KB, MMPs dan reseptor estrogen. Penghentian siklus sel dan meningkatkan apoptosis pada sel kanker selain itu alkaloid golongan ini memiliki aktivitas antioksidan yang kuat. Berdasarkan latar belakang diatas makan perlu dilakukan pengujian aktivitas antikanker dari fraksi alkaloid kulit batang dan buah attarasa terhadap sel T47D dalam upaya pengembangan bahan alam sebagai antikanker.

\section{Bahan dan Metode}

Kulit batang dan buah attarasa diperoleh dari Desa Parsoburan, Kabupaten Toba Samosir Sumatera Utara, Indonesia. etanol 96\%, kloroform (Full Time), $n$-heksana (Full Time), natrium hidroksida (Merck), hepes (Sigma), dimetil sulfoksida (DMSO) (Sigma) Media RPMI-1640, FBS (Gibco), penicillin-streptomisin (Gibco), dan Fungizon (Amfoterisin B) 0,5\%. Selain bahan-bahan di atas juga digunakan 0,25\% tripsin - EDTA (Gibco), Fetal Bovine Serum (Gibco), PBS, [3-(4,5-dimetiltiazol-2-il)-2,5 difeniltetrazolium bromida] (Sigma), natrium dodesil sulfat dalam $\mathrm{HCl}$ $0,1 \mathrm{~N}$.

\subsection{Pembuatan Ekstrak}

Sejumlah $1 \mathrm{~kg}$ simplisia kering dimaserasi menggunakan pelarut etanol 96\%. Prosedur ekstraksi mengikuti prosedur pada penelitian [8].

\subsection{Fraksinasi Alkaloid Kasar dari Ekstrak Etanol Kulit Batang dan Buah Attarasa}

Sebanyak 5 gram ekstrak etanol ditambahkan $10 \mathrm{~mL}$ etanol, di aduk sampai semua bagian ekstrak larut, ditambahkan $40 \mathrm{~mL}$ aquadest panas dan di aduk-aduk. Kemudian di saring, filtrat dimasukkan ke dalam corong pisah $250 \mathrm{~mL}$, kemudian ditambahkan $100 \mathrm{~mL}$-heksan dan dikocok dalam corong pisah, lalu diambil lapisan atas yang merupakan lapisan n-heksan dan ditampung dalam erlenmeyer, kemudian lapisan bawah tadi dimasukkan lagi kedalam corong pisah dan ditambahkan $100 \mathrm{~mL}$ n-heksan dan dikocok kuat dalam corong pisah, kemudian diambil lapisan n-heksan dan dikumpulkan, dan diulang sampai 3 kali. Setelah 3 kali pengulangan dengan penambahan nheksan, lapisan bawah dikumpulkan dalam gelas beker kemudian ditambahkan $\mathrm{HCl} 2 \mathrm{~N}$ sampai didapat pH 3, kemudian dimasukkan lagi kedalam corong pisah dan ditambahkan $100 \mathrm{~mL}$ kloroform kemudian diaduk dengan perlahan-lahan dan dan dipisahkan lapisan bawah yang merupakan lapisan kloroform dan ditampung dalam erlenmeyer, lalu perlakuan diulangi sampai 3 kali, kemudian lapisan bawah ditampung lagi di dalam gelas beker dan 
ditambahkan dengan $\mathrm{NaOH}$ sampai di dapat $\mathrm{pH} 7$ kemudian dimasukkan lagi ke dalam corong pisah dan ditambahkan $100 \mathrm{~mL}$ kloroform kemudian dikocok dalam corong pisah dan pisahkan lapisan atas dan lapisan bawah. Lapisan bawah dikumpulkan dalam erlenmeyer kemudian lapisan atas tadi ditambah $100 \mathrm{~mL}$ kloroformdan diulangi lagi sampai 3 kali kemudian ditampung lapisan bawah dan lapisan atas di kumpulkan dalam gelas beker, selanjutnya ditambah $\mathrm{NaOH}$ sampai didapat $\mathrm{pH}$ 9, lalu dimasukkan lagi kedalam corong pisah dan ditambahkan $100 \mathrm{~mL}$ kloroform kemudian dikocok dalam corong pisah dan dipisahkan kedua lapisan tersebut. Lapisan bawah ditampung dan lapisan atas ditambah kan lagi dengan kloroform dan diulangi dengan pengocokan seperti sebelumnya sampai 3 kali. Masingmasing lapisan bawah dari $\mathrm{pH}$ 3, 7 dan 9 yang telah ditampung tadi di uapkan di dalam vakum rotary sampai didapat ekstrak kasar (crude isolat) dari masing-masing fraksi. Perlakuan diulangi terus-menerus sampai total ekstrak etanol yang ditimbang untuk mendapatkan ekstrak kasar (crude isolat) sebesar 50 gram [9].

\subsection{Uji Sitotoksik}

Sel T47D ditumbuhkan dengan kepadatan 10.000 sel/sumuran pada microplate 96 sumuran dan prosedur perlakuan uji ini mengikuti prosedur seperti yang tertera pada $[10,11]$.

\subsection{Analisis data}

Data diolah secara statistik dengan menggunakan analisis descriptive dengan program SPSS 21.

\section{Hasil Dan Pembahasan}

Hasil pengujian sitotoksisitas terhadap sel T47D menggunakan metode MTT. Aktivitas dehidrogenase mitokondria sel yang hidup akan mereduksi warna kuning MTT membentuk warna ungu. Warna gelap dan berserabut yang nampak pada pengamatanmerupakan kristal formazan setelah pemberian MTT. Pada sel yang mati tidak ditemukan kristal ungu formazan, tetapi tetap kuning seperti medium. Nilai $\mathrm{IC}_{50}$ masing-masing perlakuan terhadap sel T47D dapat dilihat pada Tabel 1.

Tabel 1. Nilai $\mathrm{IC}_{50}$ Fraksi Alkaloid Kulit Batang dan Buah Attarasa

\begin{tabular}{ll}
\hline Bahan Uji & ${\text { Nilai } \mathrm{IC}_{50}(\mu \mathrm{g} / \mathrm{mL})}^{\text {Fraksi Alkaloid pH 7 Kulit Batang }}$ \\
Fraksi Alkaloid pH 9 Kulit Batang & $46,60 \pm 0,19$ \\
Fraksi Alkaloid pH 7 Buah & $123,01 \pm 14,63$ \\
Fraksi Alkaloid pH 9 Buah & $35,89 \pm 1,04$ \\
\hline
\end{tabular}

Berdasarkan tabel di atas, kemudian hasilnya dianalisis menggunakan SPSS 21. Untuk memperoleh nilai IC $_{50}$ dengan tiga kali pengulangan sehingga didapatkan nilai $\mathrm{IC}_{50}$ terkecil dari fraksi alkaloid kulit batang dan buah $\mathrm{pH} 7$ adalah 46,60 $\pm 0,19 \mu \mathrm{g} / \mathrm{mL}$ dan 35,89 $\pm 1,04 \mu \mathrm{g} / \mathrm{mL}$ sedangkan fraksi alkaloid kulit batang dan buah pH 9 adalah $123,01 \pm 14,63 \mu \mathrm{g} / \mathrm{mL}$ dan $98,31 \pm 2,51 \mu \mathrm{g} / \mathrm{mL}$. Ekstrak dinyatakan aktif apabila memberikan nilai $\mathrm{IC}_{50} 10-100$ $\mu \mathrm{g} / \mathrm{mL}$. Fraksi alkaloid kulit batang dan buah $\mathrm{pH} 7$ dan fraksi alkaloid $\mathrm{pH} 9$ buah attarasa memiliki $\mathrm{IC}_{50}$ dibawah 100 $\mu \mathrm{g} / \mathrm{mL}$ [12]. Semakin kecil nilai IC $_{50}$ berarti semakin tinggi nilai aktivitas sitotoksiknya. Maka dapat dikatakan bahwa EEBA mempunyai aktivitas sitotoksik yang poten terhadap sel kanker 4T1.

Alkaloid dari genus ini adalah golongan isoquinolin. Senyawa alkaloid isoquinolin dan quinolin memiliki efek antikanker. Berberin adalah contoh alkaloid isoquinolin. Beberapa penelitian telah menunjukkan bahwa berberin memiliki potensi sebagai antikanker pada eksperimen in-vitro dan in-vivo. Berberin menghambat proliferasi sel kanker dengan menginduksi siklus sel istirahat pada fase G1 atau G2/M dan menginduksi apoptosis [13-15] dengan meregulasi CDK [13,16], Bcl-2, Bax, Bcl-X1 [13,14,16], dan kaspase [14,16]. Berberin menginduksi endoplasmic reticulum stress dan auotophagy dalam sel kanker [17]. Berberin juga diidentifikasi sebagai inhibitor telomerase [13]. 


\section{Kesimpulan}

Berdasarkan pembahasan diatas, dapat disimpulkan bahwa fraksi alkaloid kulit batang dan buah attarasa memiliki aktivitas antikanker terhadap sel T47D.

\section{Ucapan Terima Kasih}

Penulis mengucapkan terima kasih kepada Rektor Universitas Sumatera Utara melalui "Hibah Penelitian Dasar TALENTA" tahun 2017 dalam pembiayaan penelitian ini, dengan nomor kontrak penelitian "No: 5338/UN5.1.R/PPM/2017".

\section{DAFTAR PUSTAKA}

1. Ferlay J, Shin HR, Bray F, Forman D, Mathers C, Parkin DM. Estimates of worldwide burden of cancer in 2008: GLOBOCAN 2008. International journal of cancer. 2010 Dec 15;127(12):2893-917.

2. Jemal A, Siegel R, Xu J, Ward E. Cancer statistics, 2010. CA: a cancer journal for clinicians. 2010 Sep 1;60(5):277300.

3. Bradley CJ, Yabroff KR, Dahman B, Feuer EJ, Mariotto A, Brown ML. Productivity costs of cancer mortality in the United States: 2000-2020. JNCI: Journal of the National Cancer Institute. 2008 Dec 17;100(24):1763-70.

4. Trisonthi P, Sato A, Nishiwaki H, Tamura H. A new diterpene from Litsea cubeba fruits: structure elucidation and capability to induce apoptosis in HeLa cells. Molecules. 2014 May 23;19(5):6838-50.

5. Piyapat T, Kana M, Hirotoshi T. Induction of Apoptosis in HeLa cells by Methanolic Extract of Litsea cubeba Fruit Residue from Essential. Journal of Life Sciences. 2013 Sep;7(9):928-34.

6. Dalimunthe A, Achmad S, dan Satria D. Phenolic, flavonoid content and antioxidant activities of ethylacetate extract of Litsea cubeba (Lour.) Pers. Barks. Der Pharma Chemica. 2016 8: 466-468.

7. Feng T, Zhang RT, Tan QG, Liu YP, Cai XH, Luo XD. Two new isoquinoline alkaloids from Litsea cubeba. Zeitschrift für Naturforschung B. 2009 Jul 1;64(7):871-4.

8. Satria D, Furqan M, Hadisahputra S. Rosidah. Combinational Effects Of Ethylacetate Extract Of Picria Fel-terrae Lour and Doxorubicin On T47d Breast Cancer Cells. International Journal of Pharmacy and Pharmaceutical Sciences. 2015;7(7):73.

9. Atta-ur-Rahman, Atia-tul-Wahab, Zia Sultani S, Nawaz SA, Choudhary MI. Bisbenzylisoquinoline alkaloids from Cocculus pendulus. Natural product research. 2009 Sep 20;23(14):1265-73

10. Satria D, Silalahi J, Haro G, Ilyas S, Hsb PA. Antioxidant and Antiproliferative Activities of an Ethylacetate Fraction of Picria Fel-terrae Lour. Herbs. Asian Pacific journal of cancer prevention: APJCP. 2017;18(2):399.

11. Adina AB, Goenadi FA, Handoko FF, Nawangsari DA, Hermawan A, Jenie RI, Meiyanto E. Combination of ethanolic extract of Citrus aurantifolia peels with doxorubicin modulate cell cycle and increase apoptosis induction on MCF-7 cells. Iranian journal of pharmaceutical research: IJPR. 2014;13(3):919.

12. Weerapreeyakul N, Nonpunya A, Barusrux S, Thitimetharoch T, Sripanidkulchai B. Evaluation of the anticancer potential of six herbs against a hepatoma cell line. Chinese medicine. 2012 Dec;7(1):15.

13. Sun Y, Xun K, Wang Y, Chen X. A systematic review of the anticancer properties of berberine, a natural product from Chinese herbs. Anti-cancer drugs. 2009 Oct 1;20(9):757-69.

14. Eom KS, Kim HJ, So HS, Park R, Kim TY. Berberine-induced apoptosis in human glioblastoma T98G cells is mediated by endoplasmic reticulum stress accompanying reactive oxygen species and mitochondrial dysfunction. Biological and Pharmaceutical Bulletin. 2010 Oct 1;33(10):1644-9.

15. Burgeiro A, Gajate C, Dakir EH, Villa-Pulgarín JA, Oliveira PJ, Mollinedo F. Involvement of mitochondrial and B-RAF/ERK signaling pathways in berberine-induced apoptosis in human melanoma cells. Anti-cancer drugs. 2011 Jul 1;22(6):507-18.

16. Mantena SK, Sharma SD, Katiyar SK. Berberine, a natural product, induces G1-phase cell cycle arrest and caspase3-dependent apoptosis in human prostate carcinoma cells. Molecular cancer therapeutics. 2006 Feb 1;5(2):296308.

17. Wang N, Feng Y, Zhu M, Tsang CM, Man K, Tong Y, Tsao SW. Berberine induces autophagic cell death and mitochondrial apoptosis in liver cancer cells: the cellular mechanism. Journal of cellular biochemistry. 2010 Dec 15;111(6):1426-36. 